Please note that this PDF file replaces the first version of the manuscript e044, in which Figure 7 was inadvertently omitted. 


\title{
The influence of temperature in a capillary imbibition salt weathering simulation test on Mokattam limestone
}

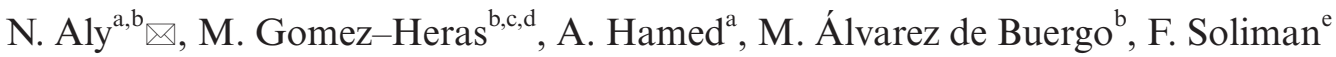 \\ a. Suez University, (Suez, Egypt) \\ b. Instituto de Geociencias (CSIC, UCM) (Madrid, Spain) \\ c. CEI Campus Moncloa (UPM, UCM, CSIC) (Madrid, Spain) \\ d. Universidad Politécnica de Madrid (Madrid, Spain) \\ e. Suez Canal University (Ismalia, Egypt) \\ \neven.ali@suezuniv.edu.eg
}

Received 22 January 2014

Accepted 14 May 2014

Available on line 29 January 2015

\begin{abstract}
Limestone is one of the most frequent building stones used in monuments in Egypt from ancient Egyptian times and salt weathering is one of the main threats to these monuments. During this work, cylindrical limestone samples ( $2 \mathrm{~cm}$ diameter and approx. $4 \mathrm{~cm}$ length) from Mokattam group, one of the most frequent materials in historic Cairo, were subjected, in a purpose-made simulation chamber, to laboratory salt weathering tests with a $10 \%$ weight $\mathrm{NaCl}$ solution at different temperatures $\left(20,30,40{ }^{\circ} \mathrm{C}\right)$. During each test, temperature was kept constant and salt solutions flowed continuously imbibing samples by capillary rise resembling the way they get into building stone in many real cases. Air temperature, relative humidity inside the simulation chamber and also samples weight were digitally monitored and recorded. Results show the influence of temperature and the ratio between imbibitions and evaporation on the dynamics of salt crystallization in the samples.
\end{abstract}

KEYWORDS: Stone decay; Salt weathering; Limestone; Durability

Citation / Citar como: Aly, N.; Gomez-Heras, M.; Hamed, A.; Álvarez de Buergo, M.; Soliman, F. (2015) The influence of temperature in a capillary imbibition salt weathering simulation test on Mokattam limestone. Mater. Construcc. 65 [317], e044 http://dx.doi.org/10.3989/mc.2015.00514.

RESUMEN: La influencia de la temperatura en un ensayo simulado de deterioro por sales mediante absorción capilar en la caliza de mokattam. Los monumentos egipcios se construyeron frecuentemente con caliza desde la antigüedad y uno de sus principales agentes de deterioro son las sales. Por ejemplo, en la zona histórica de El Cairo son frecuentes las calizas del grupo Mokattam. Cilindros $(2 \mathrm{~cm}$ de diámetro y aproximadamente $4 \mathrm{~cm}$ de altura) de esta caliza se sometieron a ensayos de deterioro por sales en una cámara experimental específicamente diseñada. Se utilizó una solución salina $(10 \%$ en peso de $\mathrm{NaCl})$ a diferentes temperaturas $\left(20^{\circ} \mathrm{C}, 30^{\circ} \mathrm{C}, 40{ }^{\circ} \mathrm{C}\right)$ que se mantuvieron constantes en cada ensayo. La solución fluía constantemente embebiendo las muestras por capilaridad, simulando lo que ocurre en casos reales. La temperatura del aire, humedad relativa en la cámara y peso de las muestras se monitorizaron con sensores digitales. Los resultados muestran la influencia de la temperatura y del balance entre imbibición y evaporación en la dinámica de la cristalización de sales en las muestras.

PALABRAS CLAVE: Deterioro de la piedra; Deterioro por sales; Caliza; Durabilidad

Copyright: (C) 2015 CSIC. This is an open-access article distributed under the terms of the Creative Commons Attribution-Non Commercial (by-nc) Spain 3.0 License. 


\section{INTRODUCTION}

Porous limestone is a traditional building material worldwide. This material is particularly susceptible to salt weathering, which in turn caused important damages in archaeological sites. (1-6). The mechanism of salt precipitation and consequent weathering forms are controlled by the petrographical characteristics of the limestone, as well as the dominant environmental conditions, e.g. air temperature and relative humidity (7-9), also the type of salt and its concentration are affected factors. Damage is controlled by the number and intensity of weathering cycles, as well as the limits of rock geotechnical parameters (10). A number of factors influence salt crystallization damage in porous materials, including: pore size and porosity, the nature of the salt, the ease with which it achieves high saturations by evaporation and/or variations in environmental temperature and, the energy difference between the crystal and the pore wall, the transport of the solution, in terms of the supply rate of the solution and the evaporation of water and strength, which is the material's resistance to crystallization pressure (11).

A commonly used method for understanding the mechanics of natural deterioration is the simulation, under controlled laboratory conditions, of salt weathering dynamics, by subjecting samples to various environmental regimes and carrying out imbibitions-drying tests $(2,12,13)$ and also the environmental cabinets which allow the accurate control of temperature and humidity cycles and by testing the resulted samples using different techniques, this may give us more details about salt crystallization and its relation to deterioration of the natural stones.

In this specific case, solutions were imbibed by capillarity, without applying any external pressure, as this is one of the main mechanisms for solution transport in the built environment. Once the stone is loaded with a saline solution, heating regimes and evaporation rates will affect to how and where salts crystallize within the stone, and therefore controlling the kind of damage generated (14). The extent of damage depends on the location of salt crystallization, if it occurs within the stone matrix (subflorescence) or at the surface (efflorescence) $(1,15)$. Although efflorescences can be easily noticed, they are less harmful comparing with subflorescences, which are more relevant to the damage and lose of the stone surface, (16). The location of crystallisation is mainly controlled by the dynamic balance between three rates which are: the rate of moisture loss through evaporation, the rate of moisture ingress by capillary flow and the rate of ion back diffusion due to the concentration gradient established within the salt solution (16).
This paper focuses mainly on study the effect of different temperature regimes on controlling the evaporation rate in a salt weathering test based on capillary rising in a continuous flow of salt solution by analyzing the resulting decay state of the limestone cores.

\section{MATERIALS AND METHODS}

Limestone samples were extracted from Helwan area south of Mokattam, which is, probably, the most famous limestone quarry in Egypt (Fig. 1). Limestone from the Mid-Eocene Mokattam Group is quarried at Helwan. This material is mostly micritic with different amount of fossil content (17).

Sodium Chloride was used during this work, as it is both a salt commonly found in buildings and it is frequently used in accelerated decay tests and the computer models (18-22). Sodium Chloride is the most common type in the subsurface water of Egypt and in sea spray coming from the Mediterranean Sea. In addition, sodium chloride does not show phase transitions that could complicate the interpretation of results. Therefore, a $10 \% \mathrm{NaCl}$ solution in distilled water was deemed adequate to this study.

The samples were prepared as $\varnothing 2 \mathrm{~cm}$ and $4 \mathrm{~cm}$ height cores. Samples were then isolated by its circumference with sealing tape to prevent water from evaporation through the side. One of the two exposed faces was kept immersed inside water flow while the other face was subjected to a certain temperature. This procedure intended to force the evaporation through only the top surface, concentrating the possible resulting crystallized salt in this area and allowing analyzing the distribution inside the sample along its height.

The limestone cores were subjected to cycles at different temperatures $\left(20{ }^{\circ} \mathrm{C}, 30^{\circ} \mathrm{C}, 40{ }^{\circ} \mathrm{C}\right)$ in a purpose-made simulation chamber designed by Hamed et al. (23). This chamber is based on feeding samples by capillary imbibitions. Standardized salt decay tests are usually on the total immersion of samples in a salt solution followed by drying (e.g. ASTM C-88, ASTM C-218, DIN 52111, RILEM 1980, V-1a, V-1b, V-2 and UNE-EN 12370). However, Benavente et al. (2) already discussed the advantages of partial immersion methods in comparison to the European standard UNE-EN 12370 and concluded these methods replicate better the salt crystallization dynamics in real cases than total immersion methods.

The chamber designed for this research is composed of a set of three drawers, stiffed vertically and made of polyvinyl chloride. Each drawer contains 32 sample containers; all of them connected for water supply and drainage. The upper and bottom drawers are also equipped with temperature/humidity 


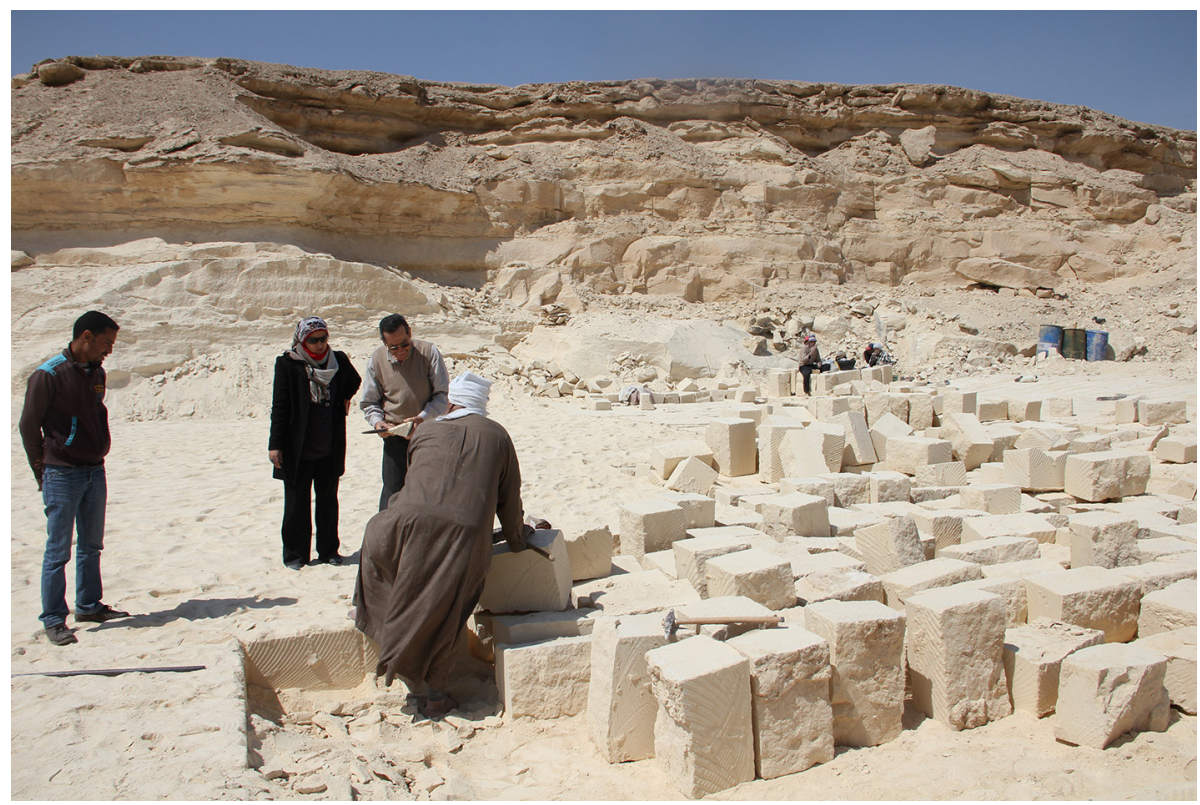

FIGURE 1. Limestone quarry, Helwan area, Egypt.

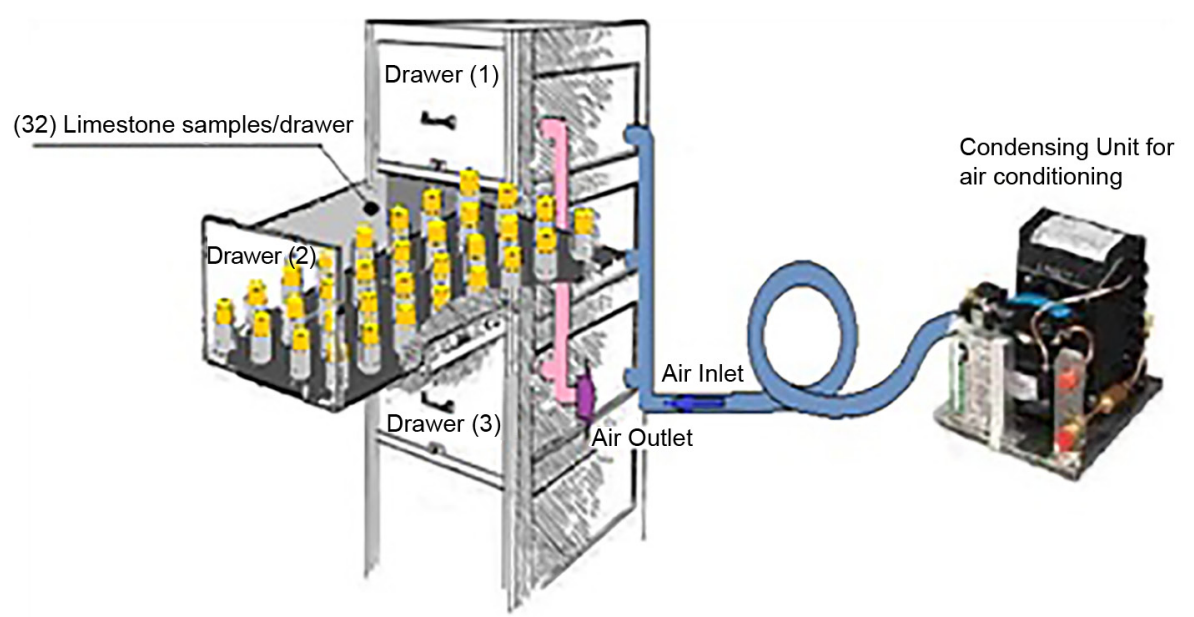

FIGURE 2. Sketch of the simulation chamber designed for these experiments.

measuring sensors. The middle drawer is equipped with a sensor attached directly to an automatically controlled air conditioning system, which keeps the temperature constants throughout the tests. Each drawer has two sets of ducts for air, one for inlet and the other for outlet, (Fig. 2).

Once samples were kept to each of the three temperature regimes $\left(20{ }^{\circ} \mathrm{C}, 30{ }^{\circ} \mathrm{C}, 40{ }^{\circ} \mathrm{C}\right)$, they were subjected to the flowing $\mathrm{NaCl}$ solution for 144 hours. In addition to this, another experiment was performed at $20{ }^{\circ} \mathrm{C}$ using only distilled water without salts to study the effect of water movement inside stone. In each experiment 72 core samples were tested and a subset of 18 samples was removed after 24, 48, 72 and 144 hours for each different test.

Petrographic examination was carried out with a polarizing microscope (Olympus BX51 TF) with an incorporated digital camera. Two thin sections were prepared for fresh cores and two more, one after $24 \mathrm{~h}$ and another after $144 \mathrm{~h}$ for each different simulation regime. Thin sections were prepared in dry conditions to avoid the dissolution of salts. 
Samples were then analyzed using the following equipments to evaluate their state after each set of laboratory regimes. Ion Chromatography (compact IC $761 \mathrm{Metrohm}$ ) was used to measure salts content and to determine salt distribution in the sample. Two cores were selected from the 18 samples subsets after $24 \mathrm{~h}$ and $144 \mathrm{~h}$ for each different simulation regime and were divided into five equal discs from the core base to the top. Each part was individually ground, dried in an oven at $50{ }^{\circ} \mathrm{C}$ till they reached constant weight. Salts from the ground samples were then dissolved in distilled water and the obtained solution analyzed.

A portable moisture meter (GE Protimeter) was used to calculate a resistivity-based parameter (Wood Moisture Equivalent-WME\%), as a surrogate of water and salts content inside each sample as both high moisture levels and high salt content can give high WME values. Five cores of each cycle were marked vertically at each $0.5 \mathrm{~cm}$ and the readings around them were taken.

Mercury intrusion porosimetry has been used for determination the distributions of pore size and volume; a Micromeritics Autopore IV9500 with a maximum injection pressure of $230 \mathrm{MPa}$ was used during this study and two cores, one fresh and another for the $20^{\circ} \mathrm{C}$ test after $144 \mathrm{~h}$ to check the changes in porous media.

Surface color is one of the most important characters for natural monumental stones. It changes during degradation process influencing the aesthetical value of the stone. As color is a very subjective phenomenon, we need to quantify it in order to avoid the different perceptions of the human eye $(24,25)$. The color was measured using spectrophotometer (MINOLTA CM-2002) with D65 illuminant and $10^{\circ}$ standard observers. $\mathrm{L}^{*}, \mathrm{a}^{*}$ and $\mathrm{b}^{*}$ according to CIE LAB system (26) and white and yellow indices according to ASTM E313 standard (27) were the parameter measured for quarry samples and after the different simulation cycles to follow the degradation process.

Surface roughness influences the colour of the material (28) and it also plays an important role in the surface degradation e.g. exposed specific surface etc. It is determined by the surface finish of the stone, its texture, grain size, and porosity. During the degradation it can be changed by the dissolution of the rock forming minerals, the precipitation of new minerals, formation of surface cracks etc. An optical roughness device (TRACEiT) was selected for measuring surface topographic changes. This device uses 3 white lights at an angle of $120^{\circ}$ generating 3D topographic models of a $5 \times 5 \mathrm{~mm}$ area of the surface (with a 1 micrometer accuracy for depth/height and a 2.5 micrometers accuracy in the horizontal axes and calculates values for $\mathrm{Ra}$, $\mathrm{Rq}$ and $\mathrm{Rz}$ roughness parameters according to

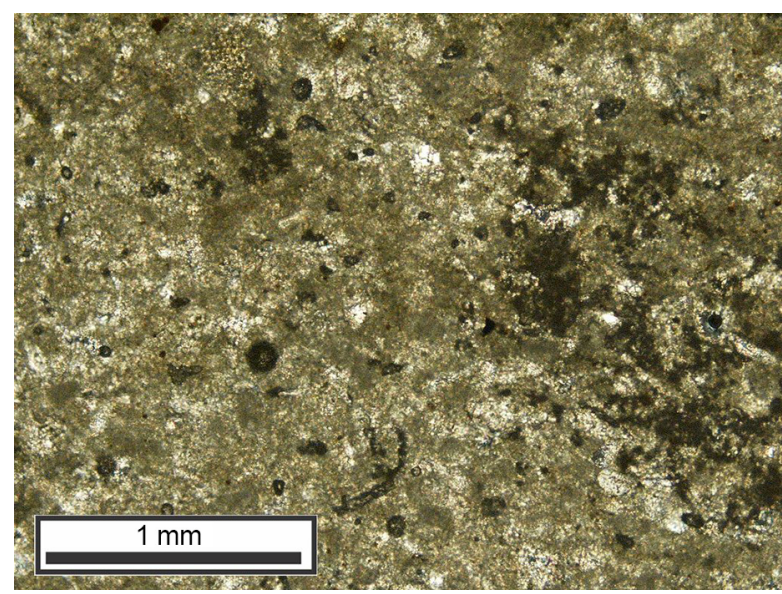

Figure 3. Photomicrograph of the samples from Helwan quarry used in this experiment.

DIN EN ISO 4287 standard (29). Five cores were selected from each of the subsets of 18 samples removed after 24, 48, 72 and $144 \mathrm{~h}$ for each different simulation regime to measure optical roughness parameters and for obtaining TRACEiT images and 3D models. Five measurements were carried out on each of the selected cores.

\section{RESULTS AND DISCUSSION}

Thin sections reveal tested samples (Fig. 3) range from biomicrite to fossiliferous micrite according Folk classification (30). $\mathrm{NaCl}$ was hardly observed in thin section. This may be due to it being destroyed during thin section preparation (31). However some $\mathrm{NaCl}$ crystals were seen growing in pores (Fig. 4b). Porosity decreases during $20{ }^{\circ} \mathrm{C}, 30^{\circ} \mathrm{C}$ and $40{ }^{\circ} \mathrm{C}$ regimes cycles (Fig. 4a, b, c) in comparison to fresh quarry samples. The opposite trend is seen in samples tested with distilled water as pores with different sizes come into sight (Fig. 4d). Also initiation of micro cracks is visible in some thin sections of $30^{\circ} \mathrm{C}$ and $40{ }^{\circ} \mathrm{C}$ regimes (Fig. $4 \mathrm{c}$ ).

After the different simulation regimes, the upper surface of cores subjected to salt circulation become visibly darker and rougher with time. This is mostly noticeable in $40{ }^{\circ} \mathrm{C}$ regime (Fig. 5) where obvious cracking, scaling and spalling parallel to the exposed surface appears in most samples. Contrarily, in $30{ }^{\circ} \mathrm{C}$ regime sample, the upper surface of the cores appears lighter due to efflorescences crystallized on this surface.

The average weight increase at the end of the distilled water test was very limited as expected $(0.38 \%$ of the initial weight). Weight increase for $20^{\circ} \mathrm{C}$ tests was $1.8 \%$ and reached up to $2.6 \%$ after the $30{ }^{\circ} \mathrm{C}$ tests. This is the most noticeable weight increase due to the accumulation of salt crystallization on the 

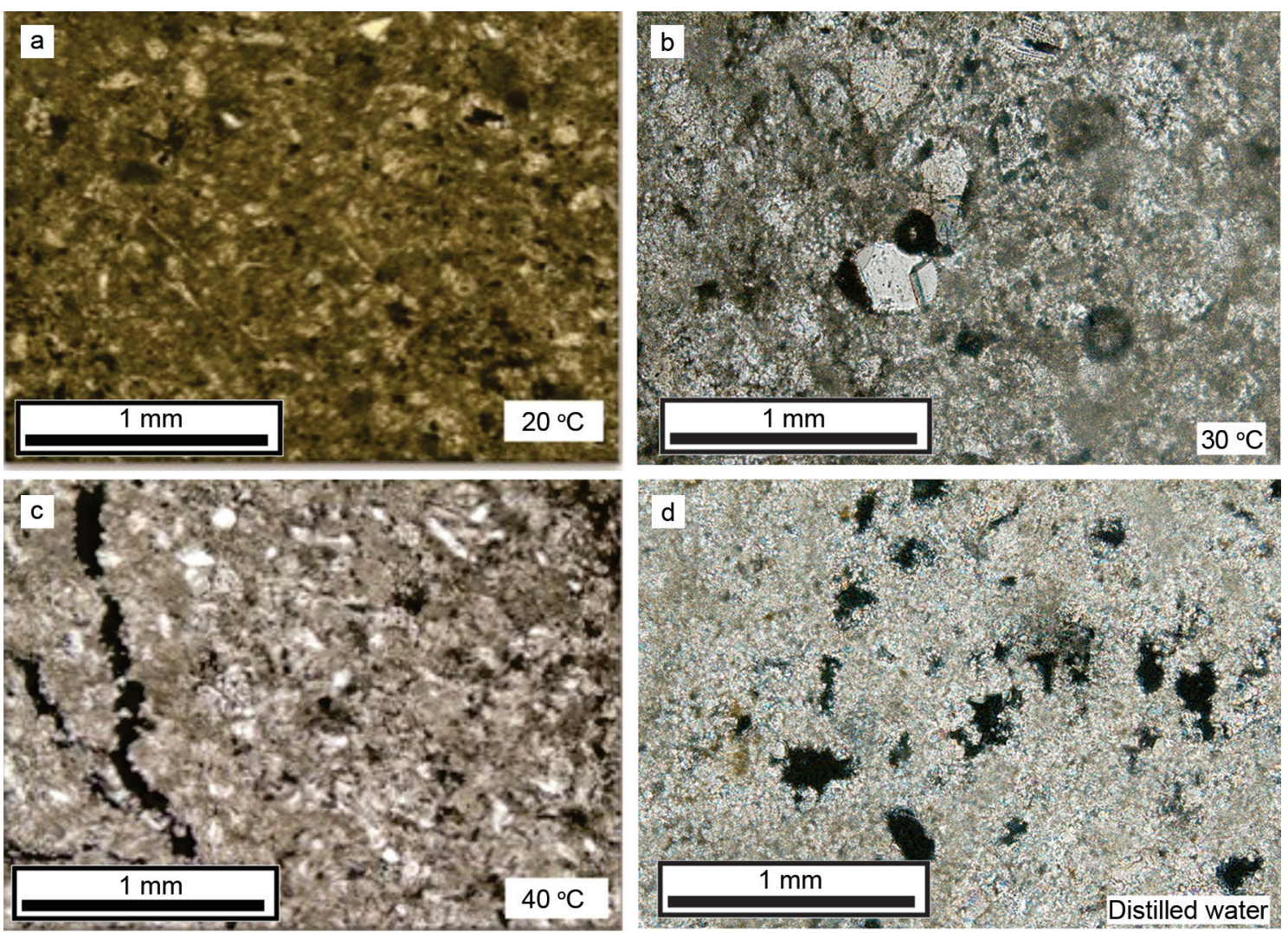

Figure 4. Photomicrographs of thin sections after $144 \mathrm{~h}$ for $20^{\circ} \mathrm{C}(\mathrm{PPL}), 30^{\circ} \mathrm{C}(\mathrm{PPL}), 40^{\circ} \mathrm{C}(\mathrm{XN})$ and distilled water (XN) regimes.

core surfaces. After the $40{ }^{\circ} \mathrm{C}$ test a slight weight increase of $0.13 \%$ of the initial weight was detected, as the loss of material in most of the cores compensated any possible increase due to salt accumulation.

Ion Chromatography (Fig. 6) shows how $\mathrm{NaCl}$ distribution varies in relation to time and the temperature of the experimental regime. In all cases it is visible how $\mathrm{NaCl}$ tends to concentrate both at the bottom and the top of the sample. In $20^{\circ} \mathrm{C}$ experimental setup, $\mathrm{NaCl}$ increases from $8.4 \mathrm{mg} / \mathrm{L}$ to a maximum of $76 \mathrm{mg} / \mathrm{L}$ while in the rest of regimes this increase is much higher.

In $30{ }^{\circ} \mathrm{C}$ regime, salt increase in the last upper centimetre is higher than in any other cases, which reflects the growth of efflorescences on the top of

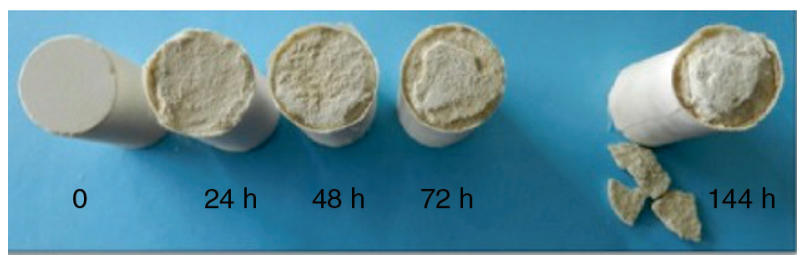

FIGURE 5. Visual appearance of cores during the $40{ }^{\circ} \mathrm{C}$ experimental regime. the sample. In $40{ }^{\circ} \mathrm{C}$ experimental regime, salts concentrate rapidly towards the top of the sample, as cores show an evident enrichment in $\mathrm{NaCl}$ already after $24 \mathrm{~h}$ and it barely changes from the sample after $24 \mathrm{~h}$ to the sample after $144 \mathrm{~h}$. This contrasts with the other experimental setups, in which this intense enrichment just comes towards the end of the experiments, i.e. in the cores sampled after $144 \mathrm{~h}$. It must be noted only four slices could be obtained in the $40{ }^{\circ} \mathrm{C}$ core after $144 \mathrm{~h}$ as the top surface was lost due to the mechanical breakdown caused by the growth of subefflorescences.

The bottom part shows enrichment in $\mathrm{NaCl}$, but this should be interpreted as a result of the evaporation occurring in the bottom surface from the moment the cores are removed from the experimental chamber to the moment they are analysed.

Figure 6 also shows the results of WME (\%) obtained with the protimeter. At first glance, these values would seemingly contradict the IC results as the maximum values appear in the middle of the core instead of in the base and the top. Measures carried out at different environmental Relative Humidity showed that while the pattern was constant, the absolute values increased with the environmental humidity. This highlights the complexity 


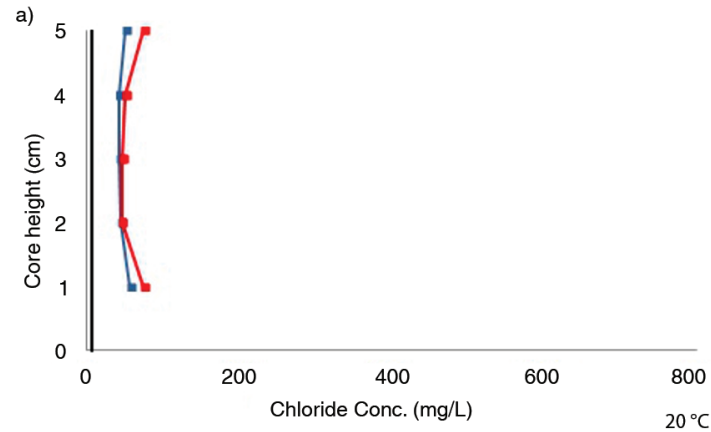

b)

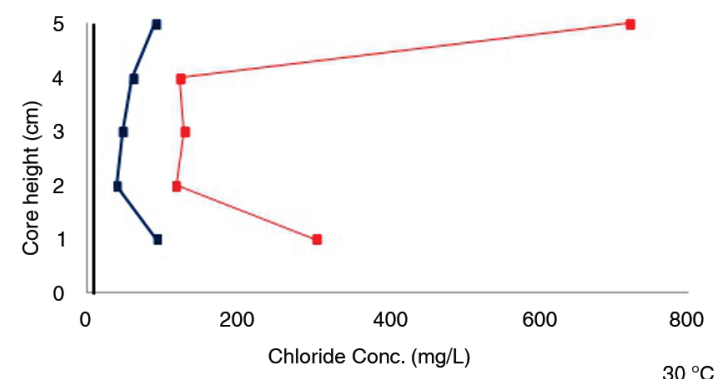

c)

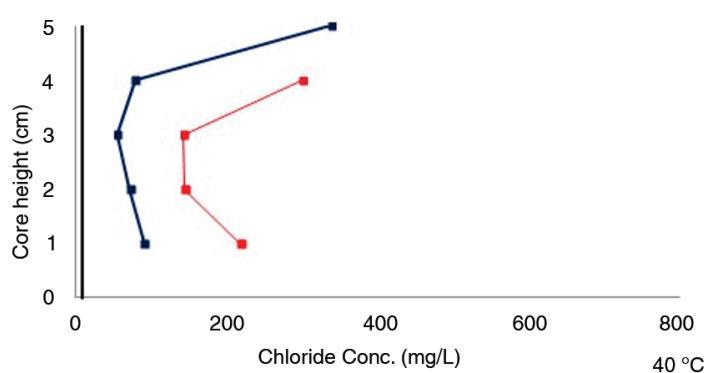

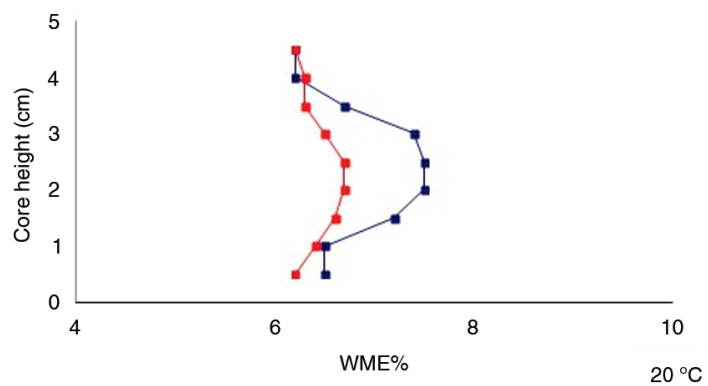

e)

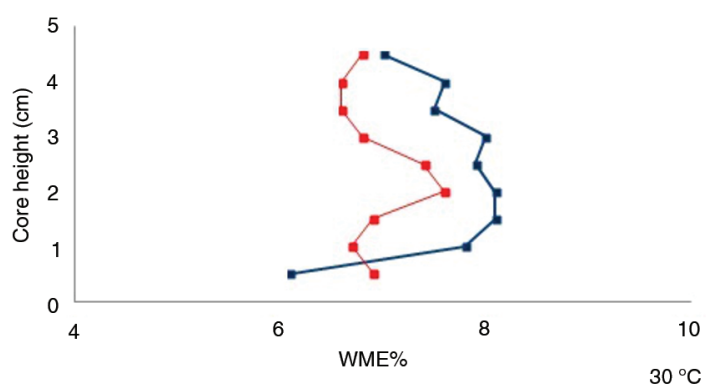

f)

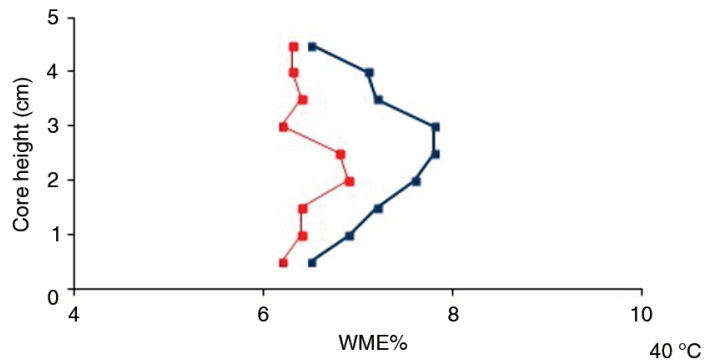

$\rightarrow-144 \mathrm{~h}$

Figure 6. Results of Ion Chromatography and WME $\%$ in the different experimental regimes.

of interpreting the readings from portable moisture meters when there is a combined presence of moisture and salts.

Figure 7 shows the results of MIP porosity and pore size distributions of a fresh core and another after $144 \mathrm{~h}$ at $20{ }^{\circ} \mathrm{C}$. The total porosity accessible to mercury of the fresh core equals to $33.4 \%$ and it decreases to be $22.5 \%$ after the $20^{\circ} \mathrm{C}$ test, as a result of salt crystallization within the pores. The average pore diameter (4V/A) increases slightly from 0.14 to $0.16 \mu \mathrm{m}$ as well as the relative intensity of a secondary peak at $0.65 \mu \mathrm{m}$.

Colour results are summarized in Table 1. L, a* and $b^{*}$ barely changes in all tests while White and Yellow indices (Fig. 8) show changes throughout the experiments except for the ones where samples were subjected just to distilled water. On one hand, in $20{ }^{\circ} \mathrm{C}$ and $40{ }^{\circ} \mathrm{C}$ regimes, WI decreases and YI increases progressively, being these changes more intense in $40{ }^{\circ} \mathrm{C}$ regime. On the other hand, WI decreases and YI increases only during the first $24 \mathrm{~h}$ of $30^{\circ} \mathrm{C}$ regime. After this, the opposite trend is seen, i.e. WI increases and YI decreases as the result of the appearance of white $\mathrm{NaCl}$ efflorescences on the top surface.

Examples of TRACEiT images and 3D models of the top surface of fresh cores and after $144 \mathrm{~h}$ of testing at the different temperatures are represented in Figure 9. These 3D models show the change of surface topography after different temperature regimes. $3 \mathrm{D}$ models datum is placed in the lowest point of the topography and the vertical scale is adjusted automatically to the lowest and highest points of the topography. Therefore not all the 3D models presented show 
a)

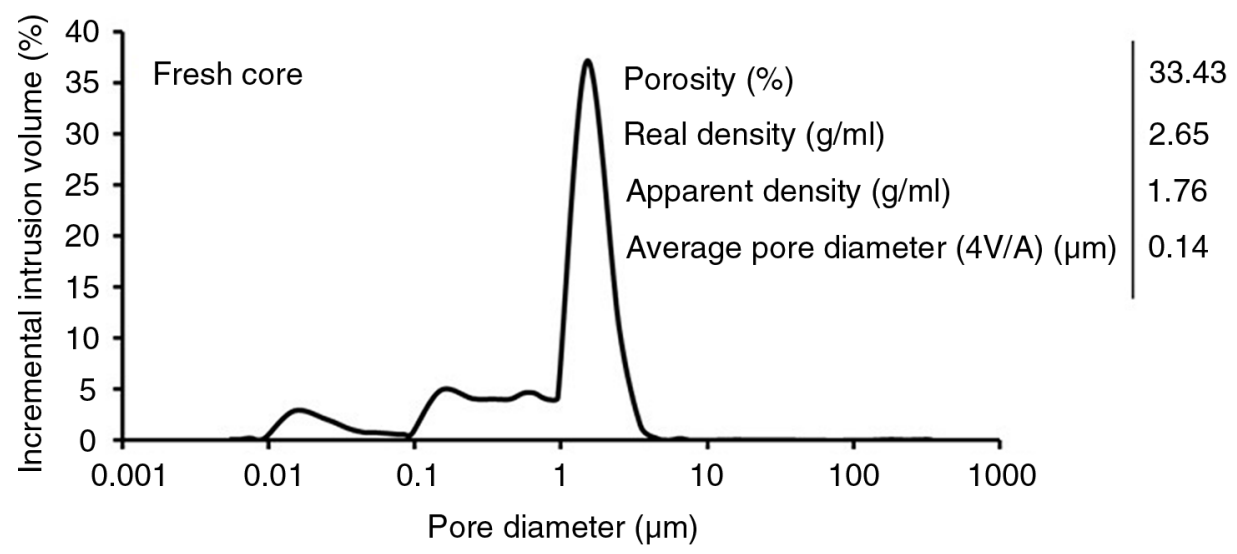

b)

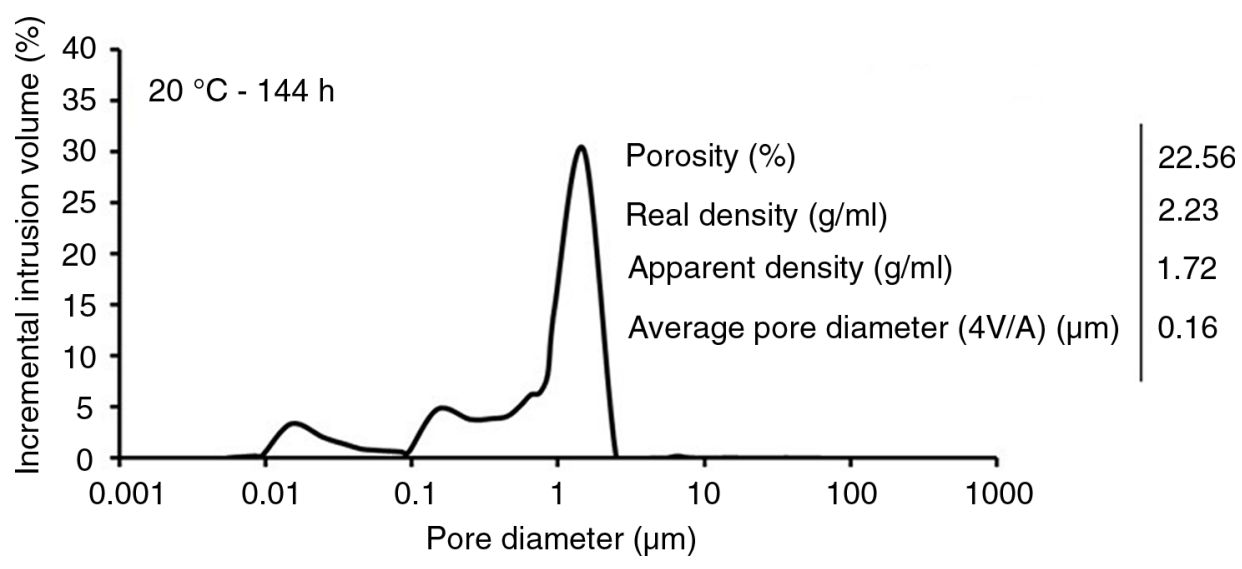

FiguRE 7. MIP porosity and pore size distributions of (a) fresh core and (b) core after $144 \mathrm{~h}-20^{\circ} \mathrm{C}$.

the same scale. Topography is highlighted by a colour scale that goes from purple and blue for the deepest parts and red for the highest parts.

The surface of the cores tested after distilled water shows a similar degree of surface roughness than the fresh ones (Fig. 9a, b). After the 20 and $30^{\circ} \mathrm{C}$ experimental regimes, surface irregularity increased (Fig. 9c, d). This is reflected on the change of the vertical scale in the figures. After $40{ }^{\circ} \mathrm{C}$ tests, the irregularity of cores surfaces noticeably increased due to the appearance of cracks. Once more, this is reflected in a noticeable change in the vertical scale of the models (Fig. 9e). Roughness index Rz is plotted in Figure 10 for each one of the regimes. Rz increases for all tests up to 48 hours. This increase is very slight for both distilled water and $20^{\circ} \mathrm{C}$ tests with $\mathrm{Rz}$ decreasing after 48 hours for distilled water tests, presumably due to dissolution of grains on the surface. The increase is more noticeable after 30 and $40{ }^{\circ} \mathrm{C}$ tests. The increase for $30^{\circ} \mathrm{C}$ may be interpreted as the results of efflorescences crystallizing on the stone surface. The decrease for $40^{\circ} \mathrm{C}$ may be considered the result of an artifact from the experimental methodology. Roughness could not be measured on the samples that had lost its original surface due to breakdown generated by salt crystallization, so only the smoother samples that had not lost its original surface could be measured. Therefore, Rz after $144 \mathrm{~h}$ for the $40{ }^{\circ} \mathrm{C}$ tests is biased towards smoother values which were not fully characteristic of the whole set of samples. In general, roughness values vary more in the samples subjected to higher temperatures and the core surfaces became rougher. At $30{ }^{\circ} \mathrm{C}$ and $40{ }^{\circ} \mathrm{C}$ a clear presence of cracks can be seen in the 3D models (Fig. 9).

Results obtained confirm previous suggestions that temperature regimes affect the way $\mathrm{NaCl}$ crystallizes on the surface as efflorescences or within the material as subefflorescences (14). Specifically, these results show how there might be certain temperature interval for which a salt would tend to crystallize within a rock instead of on its surface.

The experiments carried out show how at $20^{\circ} \mathrm{C}$ changes are, in general, very slight within the $144 \mathrm{~h}$ time spam. Under a $30{ }^{\circ} \mathrm{C}$ experimental regime, as early as after 48 hours efflorescences begin to appear on the surface of the samples, while under a $40{ }^{\circ} \mathrm{C}$ regime, salts concentrate within the core mass. 
TABLE 1. Color parameters of fresh cores and after different simulated regimes

\begin{tabular}{|c|c|c|c|c|c|}
\hline & $\mathbf{L}^{*}$ & $a^{*}$ & $\mathbf{b}^{*}$ & WI & YI \\
\hline \multicolumn{6}{|c|}{ Fresh cores } \\
\hline & $85.0 \pm 0.6$ & $\begin{array}{ll}1.5 & 0.3\end{array}$ & $10 \quad 0.6$ & 24 & $16.0 \quad 1.0$ \\
\hline \multicolumn{6}{|c|}{ Distilled water } \\
\hline $24 \mathrm{~h}$ & $85.0 \pm 1.0$ & $1.0 \pm 0.4$ & $10.0 \pm 1.0$ & $22.0 \pm 5.0$ & $17.0 \pm 2.0$ \\
\hline $48 \mathrm{~h}$ & $85.0 \pm 1.0$ & $1.0 \pm 0.3$ & $10.0 \pm 1.0$ & $24.0 \pm 6.0$ & $16.0 \pm 2.0$ \\
\hline $72 \mathrm{~h}$ & $85.0 \pm 1.0$ & $1.0 \pm 0.1$ & $10.0 \pm 1.0$ & $24.0 \pm 6.0$ & $16.0 \pm 2.0$ \\
\hline $144 \mathrm{~h}$ & $85.0 \pm 1.0$ & $1.0 \pm 0.4$ & $10.0 \pm 1.0$ & $23.0 \pm 7.0$ & $17.0 \pm 2.0$ \\
\hline \multicolumn{6}{|c|}{$20^{\circ} \mathrm{C}$} \\
\hline $24 \mathrm{~h}$ & $82.0 \pm 1.0$ & $1.0 \pm 0.2$ & $11.0 \pm 0.3$ & $15.0 \pm 1.0$ & $19.0 \pm 0.4$ \\
\hline $48 \mathrm{~h}$ & $82.0 \pm 2.0$ & $2.0 \pm 0.4$ & $12.0 \pm 1.0$ & $13.0 \pm 7.0$ & $20.0 \pm 3.0$ \\
\hline $72 \mathrm{~h}$ & $80.0 \pm 4.0$ & $1.0 \pm 0.2$ & $11.0 \pm 1.0$ & $14.0 \pm 4.0$ & $19.0 \pm 2.0$ \\
\hline $144 \mathrm{~h}$ & $80.0 \pm 2.0$ & $2.0 \pm 0.3$ & $13.0 \pm 1.0$ & $7.0 \pm 6.0$ & $22.0 \pm 3.0$ \\
\hline \multicolumn{6}{|c|}{$30^{\circ} \mathrm{C}$} \\
\hline $24 \mathrm{~h}$ & $79.0 \pm 1.0$ & $2.0 \pm 1.0$ & $12.0 \pm 2.0$ & $10.0 \pm 9.0$ & $20.0 \pm 4.0$ \\
\hline $48 \mathrm{~h}$ & $80.0 \pm 2.0$ & $2.0 \pm 0.4$ & $11.0 \pm 1.0$ & $14.0 \pm 2.0$ & $19.0 \pm 1.0$ \\
\hline $72 \mathrm{~h}$ & $80.0 \pm 1.0$ & $1.0 \pm 0.4$ & $10.0 \pm 2.0$ & $18.0 \pm 7.0$ & $18.0 \pm 3.0$ \\
\hline $144 \mathrm{~h}$ & $83.0 \pm 1.0$ & $1.0 \pm 0.4$ & $10.0 \pm 1.0$ & $22.0 \pm 5.0$ & $17.0 \pm 2.0$ \\
\hline \multicolumn{6}{|c|}{$40^{\circ} \mathrm{C}$} \\
\hline $24 \mathrm{~h}$ & $81.0 \pm 1.0$ & $2.0 \pm 0.4$ & $12.0 \pm 1.0$ & $10.0 \pm 5.0$ & $20.0 \pm 2.0$ \\
\hline $48 \mathrm{~h}$ & $80.0 \pm 2.0$ & $2.0 \pm 0.6$ & $14.0 \pm 1.0$ & $5.0 \pm 5.0$ & $23.0 \pm 2.0$ \\
\hline $72 \mathrm{~h}$ & $82.0 \pm 1.0$ & $2.0 \pm 0.6$ & $12.0 \pm 2.0$ & $6.0 \pm 8.0$ & $20.0 \pm 3.0$ \\
\hline $144 \mathrm{~h}$ & $80.0 \pm 3.0$ & $2.0 \pm 0.7$ & $14.0 \pm 3.0$ & $3.0 \pm 8.0$ & $24.0 \pm 5.0$ \\
\hline
\end{tabular}
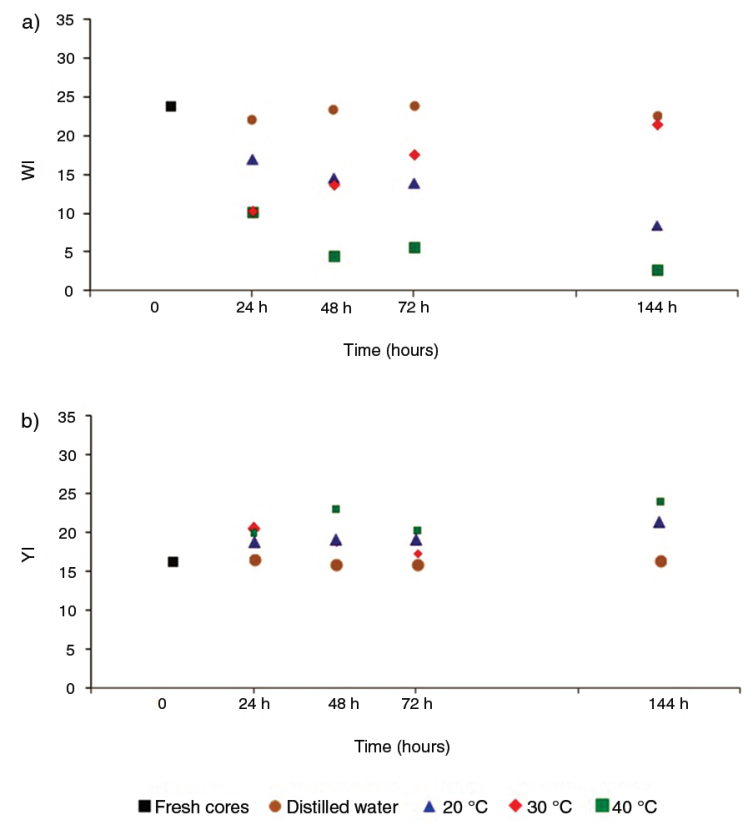

Figure 8. White (a) and Yellow (b) indices in the different experimental regimes.
In the $40{ }^{\circ} \mathrm{C}$ experimental regime, IC shows salt loading through capillary rise is more effective and more salts deeper within the core. For example, Figure 6 shows how after $144 \mathrm{~h}$ the core under a $30^{\circ} \mathrm{C}$ regime contains $124 \mathrm{mg} / \mathrm{L}$ of $\mathrm{NaCl}$ at a $4 \mathrm{~cm}$ height while under $40^{\circ} \mathrm{C}$ this amount is more than double ( $299 \mathrm{mg} / \mathrm{L})$ plus the surface is lost due to the crystallization pressure generated by salt crystallizing deeper in the core.

In $20^{\circ} \mathrm{C}$ regime, temperature is not high enough for evaporation to overcome the amount of saline solution that feeds in the core through the continuous flow of water from below. On the other end, in $40{ }^{\circ} \mathrm{C}$, temperature is high enough for evaporation to be much more effective than the ability of the rock for being fed with the solution flowing underneath. In the middle of these two situations, in $30^{\circ} \mathrm{C}$ regime it seems there is a balance between moisture ingress from the bottom by capillarity and evaporation from the top. In this situation, solution is seemingly feeding the formation of efflorescences on the surface in a continuous way. From this, it seems the balance between solution feeding and evaporation may control when and when not efflorescences appear.

\section{CONCLUSIONS}

This work highlights the importance of using realistic simulation regimes when studying the dynamics of salt crystallization in building materials. This experimental setup shows advantages in comparison to other standardized salt decay tests in which samples are soaked completely within a solution for a limited amount of time to be dried afterwards. This new proposed experimental chamber could achieve more accurate results to understand stone decay by salt crystallization, as shown by the noticeable differences tested samples show in a very short time.

The fact that a certain salt $(\mathrm{NaCl}$ in this case) appears as efflorescence or subefflorescence is dependent of the temperature regime and more specifically it is seemingly dependent on the balance between moisture ingress and evaporation (which, in turn, is controlled by the temperature regime as well).

Understanding this difference is really important due to due to more severe consequences subefflorecences have for stone conservation in terms of mechanical damage.

This has implications for hot and dry climates such as Egypt's as the balance moisture ingress and evaporation is always going to be biased towards evaporation, and therefore, salts would be more prone to be found as subefflorescences, which tend to be more disruptive for building materials than efflorescences. 
The influence of temperature in a capillary imbibition salt weathering simulation test on Mokattam limestone $\bullet 9$
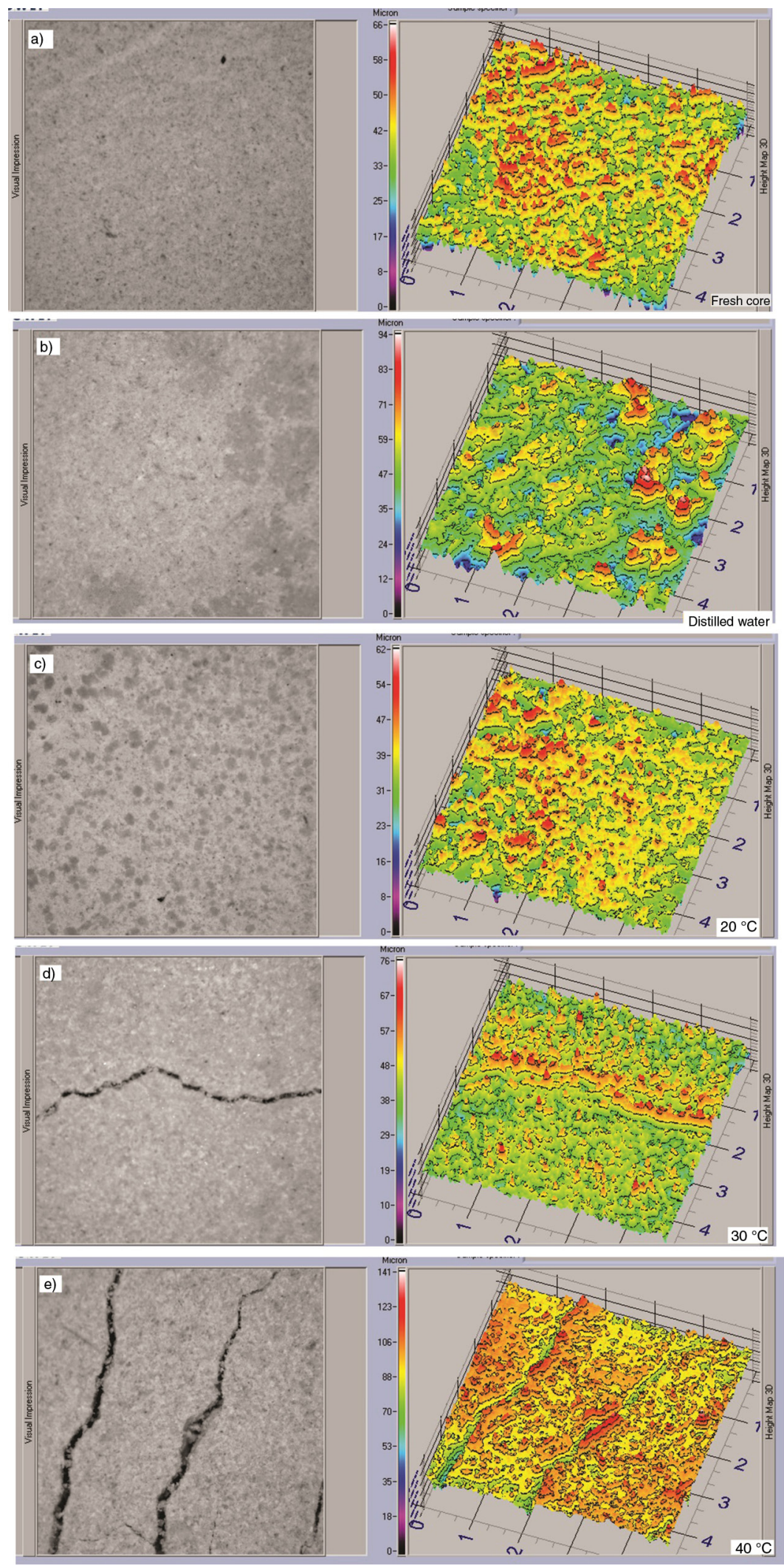

FIGURE 9. TRACEiT images and 3D models of fresh and tested samples. Image size is $5 \times 5 \mathrm{~mm}$. 

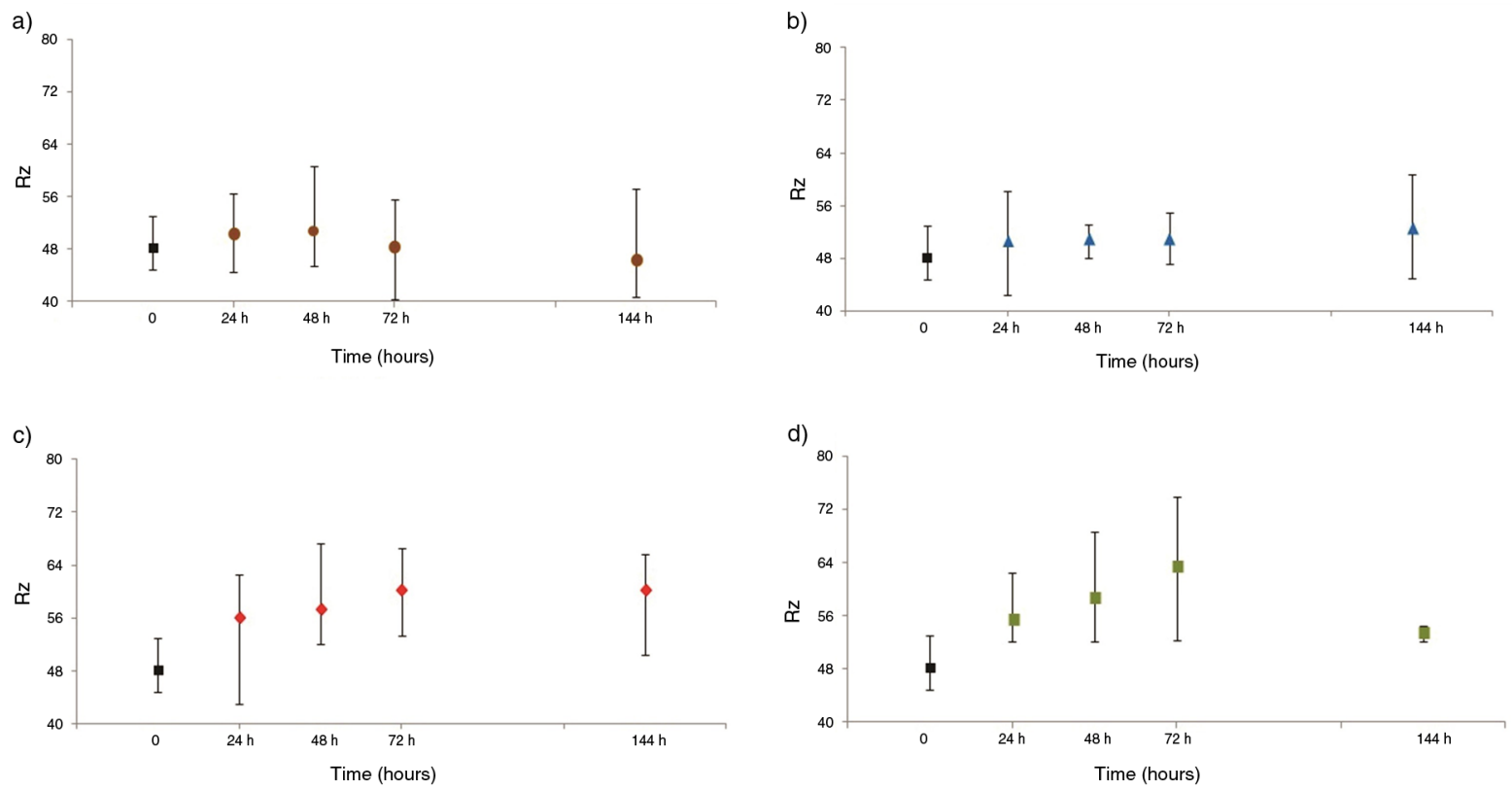

\footnotetext{
a Fresh cores Distillated water $\triangle 20^{\circ} \mathrm{C} \quad 30^{\circ} \mathrm{C} \quad 40^{\circ} \mathrm{C}$
}

FIGURE 10. Rz roughness parameter after the different experimental regimes.

\section{ACKNOWLEDGEMENTS}

We would like to thank to the Mission Sector of the High Education Ministry, Egypt and Geomateriales 2 S2013/MIT-2914 (Madrid) for financial support. We also thank Rock Mechanics Laboratory, Faculty of Pet. \& Min. Engineering-Suez University, Egypt and the Petrophysics Laboratory at the Instituto de Geociencias IGEO (CSIC, UCM). MG was supported by a PICATA postdoctoral fellowship of the Moncloa Campus of International Excellence (UCM-UPM, CSIC).

\section{REFERENCES}

1. Rodriguez, N.C.; Doehne, E. (1999) Salt weathering: influence of evaporation rate, supersaturation and crystallization pattern. Earth Surface Processes and landforms. 24, 191-209. http://dx.doi.org/10.1002/(SICI)1096-9837(199903) 24:3<191::AID-ESP942>3.0.CO;2-G.

2. Benavente, D.; García del Cura, M.A.; Bernabeu, A.; Ordoñez, S. (2001) Quantification of salt weathering in porous stones using an experimental continuous partial immersion method. Eng. Geol. 59 [3-4], 313-325. http:// dx.doi.org/10.1016/S0013-7952(01)00020-5.

3. McBride, E.F.; Picard, M.D. (2004) Origin of honeycombs and related weathering forms in Oligocene Macigno Sandstone, Tuscan Coast near Livorno, Italy. Earth Surface Processes and landforms. 29, 713-735. http://dx.doi.org/10.1002/esp.1065.

4. Gomez-Heras, M.; Benavente, D.; Alvarez de Buergo, M.; Fort, R. (2004) Soluble salt minerals from pigeon droppings as potential contributors to the decay of stone based Cultural Heritage. Eur. J. Mineral. 16, 505-509. http:// dx.doi.org/10.1127/0935-1221/2004/0016-0505.

5. Scherer, G.W. (2004) Stress from crystallization of salt Cem. Concr. Res. 34, 1613-1624. http://dx.doi.org/10.1016/j. cemconres.2003.12.034.
6. Kamh, G.; Kallash, A.; Azzam, R. (2008) Factors controlling building susceptibility to earthquakes: 14 -year recordings of Islamic archaeological sites in Old Cairo, Egypt: a case study. Environ. Geol. 56, 269-279. http://dx.doi.org/ 10.1007/s00254-007-1162-3.

7. Fitzner, B.; Heinrichs, K.; La Bouchardiere, D. (2003) Weathering damage on Pharaonic sandstone monuments in Luxor-Egypt. Build. Environ. 38, 1089-1103. http://dx.doi. org/10.1016/S0360-1323(03)00086-6.

8. Smith, B.J.; Torok, A.; McAlister, J.J.; Megarry, Y. (2003) Observations on the factors influencing stability of building stones following contour scaling: a case study of oolitic limestones from Budapest, Hungary. Build. Environ. 38 [9-10], 1173-1183. http://dx.doi.org/10.1016/ S0360-1323(03)00076-3.

9. Huinink, H.P.; Pel, L.; Kopinga, K. (2004) Simulating the growth of tafoni. Earth Surface Processes and landforms. 29, 1225-1233. http://dx.doi.org/10.1002/esp.1087.

10. Goudie, A.S. (1999) A comparison of the relative resistance of limestones to frost and salt weathering. Permafrost and Periglacial Processes. 10, 309-316. http://dx.doi.org/ 10.1002/(SICI) 1099-1530(199910/12)10:4<309::AIDPPP330>3.0.CO;2-C

11. Benavente, D.; Cueto, N.; Martínez-Martínez, J.; García del Cura, M.A.; Cañaveras, J.C. (2007) The influence of petrophysical properties on the salt weathering of porous building rocks. Environ. Geol. 52, 215-224. http://dx.doi. org/10.1007/s00254-006-0475-y.

12. Nicholson, D.T. (2001) Pore properties as indicators of breakdown mechanisms in experimentally weathered limestones. Earth Surface Processes and Landforms. 26, 819-838.

13. Chéné, G.; Bastian, G.; Brunjail, C.; Laurent, J.P. (1999) Accelerating weathering of tuffeau block submitted to wetting-drying cycles. Mater. Struct. 32 [221], 525-532. http://dx.doi.org/10.1007/BF02481637.

14. Gomez-Heras, M.; Fort, R. (2007) Patterns of halite (NaCl) crystallisation in building stone conditioned by laboratory heating regimes. Environ. Geo. 52, 239-247. http://dx.doi. org/10.1007/s00254-006-0538-0.

15. Scherer, G.W. (2000) Stress from crystallization of salt in pores. $9^{\text {th }}$ International on Deterioration and Conservation 
of Stone, Venice, New York. Elsevier, 187-194. http://dx.doi. org/10.1016/B978-044450517-0/50100-8.

16. Sawdy, A.; Heritage, A.; Pel, L. (2008) A review of salt transport in porous media, assessment methods and salt reduction treatments. SWBSS proceedings, 1-27. Ottosen LM et al. (Eds). Salt Weathering on Buildings and Stone Sculptures, Technical university of Denmark-Department of civil Engineering, Lyngby, Denmak.

17. Fitzner, B.; Heinrichs, K.; La Bouchardiere, D. (2003) Limestone weathering of historical monuments in Cairo, Egypt. In Siegesmund, S.; Weiss, T. \& Vollbrecht, A. (edit.) Natural stone, weathering phenomena, conservation strategies and case studies, Geological Society, London, Special Publication. 205, 217-239.

18. Goudie, A.S. (1974) Further experimental investigation of rock weathering by salt and other mechanical processes. Zeitschrift fur Geomorphologie supplement band. 21, 1-12.

19. Sperling, C.H.B.; Cooke, R.U. (1985) Laboratory simulation of rock weathering by salt crystallization and hydration processes in hot- arid environments. Earth Surface Processes and Landforms. 10 [6], 541-555.

20. Grossi, C.M.; Esbert, R.M. (1994) Las sales solubles en el deterioro de rocas monumentales; revisión bibliográfica. Mater. Construc. 44, 15-30. http://dx.doi.org/10.3989/mc. 1994.v44.i235.579.

21. Goudie, A. S.; Viles, H. A. (1997) Salt Weathering Hazards. John Wiley, Chichester.

22. Benavente, D.; García del Cura, M.A.; Ordoñez, S. (2003) Salt influence on evaporation from porous building rocks. Construc. Build. Mat. 17, 113-122. http://dx.doi. org/10.1016/S0950-0618(02)00100-9

23. Hamed, A.; Aly, N.; Gomez-Heras, M.; Álvarez de Buergo, M. (submitted) New experimental method to study the combined effect of temperature and salt weathering. In Prikryl $\mathrm{R}$ et al. (Eds.). Geological Society Special Publication, Sustainability of traditional construction materials in modern Geol. Soc. Publishing House, Bath, series Special Publication.

24. Mac Adam, D.L. (1985) Colour Measurement-Theme and Variations, Second Revised Edition, Springer-Verlag.

25. Prasad, K.M.; Raheem, S.; Vijayalekshmi, P.; Kamala Sastri, C. (1996) Basic aspects and applications of tristimulus colorimetry-Review-Talanta. 1187-1206.

26. Commission Internationale de l'Eclairage (CIE), (1986) Colorimetry, 2nd edition. Publication CIE 15.2. Bureau central de la CIE, Paris, France, 83

27. ASTM (2000) E313-00 Standard practice for calculating yellowness and whiteness indices from instrumentally measure color coordinates. ASTM, West Conshohocken, Pennsylvania.

28. Benavente, D.; Martínez-Verdú, F.; Bernabeu, A.; Viquiera, V.; Fort, R.; García del Cura, M.A.; Illueca, C.; Ordóñez, S. (2003) Influence of surface roughness on colour changes in building stones. Color Research and Application. 28/5, 343-351. http://dx.doi.org/10.1002/col.10178.

29. DIN (2010) EN ISO42887 Geometrical Product Specifications (GPS) - Surface texture: Profile method-Terms, definitions and surface texture parameters.

30. Folk, R.L. (1962) Classification of carbonate rocks- a symposium, American Association of Petroleum Geologists, Tulsa, Memoir. 62-84.

31. Scolle, P.A.; Scolle, D.S.U. (2003) A color guide to petrography of carbonate rocks, grains, textures, porosity, diagenesis. American Association of Petroleum Geologiests, Tulsa, Memoir. 77, $394-406$. 